\title{
STATE PURCHASING POLICY - A NEW INSTITUTION OF PUBLIC PROCUREMENT LAW
}

\author{
Ewa Katarzyna Czech*, Andrzej Panasiuk**
}

\begin{abstract}
The state's purchasing policy is one of the new institutions of the Public Procurement Law. Influenced by the changes in the package of directives coordinating public procurement procedures in 2014, our national legislator has taken steps to use public procurement for purposes other than strictly purchasing. Therefore, the authors' considerations strive to define the concept of "purchasing policy of the state", outlining the role and scope thereof in the functioning of the modern state. Furthermore, the authors try to point out problems related to its implementation by the public authorities, stating finally that purchasing policy will only be effectively implemented if all participants of the public procurement market are aware of the policy objectives.
\end{abstract}

Keywords: Public procurement law, National purchasing policy, Directives coordinating public procurement procedures

* Information about Author: Dr. habil. Ewa Katarzyna Czech, Associate Professor UwB, Faculty of Law, University of Bialystok; correspondence address: Mickiewicza 1, 15-213 Białystok, Poland; e-mail: e.czech@uwb.edu.pl; https://orcid.org/0000-00015421-4053.

** Information about Author: Dr. habil. Andrzej Panasiuk, Associate Professor UwB, Faculty of Law, University of Bialystok; correspondence address: Mickiewicza 1, 15-213 Białystok, Poland; e-mail: a.panasiuk@uwb.edu.pl; https://orcid.org/0000-0002$0847-2315$. 


\section{INTRODUCTION}

The objectives of the current policy of public authorities are usually expressed by the current government, and they de facto create the means by which the public sector will meet its expectations and the scope of these expectations ${ }^{1}$. There is a doctrinal consensus that the role public authority plays in the economy evolves towards attaining the policy objectives through stimulating participating entities rather than through directive administrative action ${ }^{2}$. It seems that the philosophy of effective government action in the area of policy implementation could be understood as creating optimal conditions for the development of a free operation of private entities in all spheres of economic and social life. Therefore, the government should designate tasks so that it can, within its competences, 'steer not row', i.e. provide services and invest in related infrastructural projects on market terms and thus, more effectively and professionally.

Efficient implementation of the state's policy ${ }^{3}$ requires an appropriate legal instruments. Therefore, purchasing policy, as a public management tool, will definitely be incorporated into public policy ${ }^{4}$.

Intuitively we all seem to know what 'state's purchasing policy' means. However, this concept appeared for the first time in the draft Public Procurement Law Act, which, according to the Act on Introductory Regulations, enters into force on 1st January $2021^{5}$. The state's purchasing policy, pursuant to Art. 22 (1) of the draft Public Procurement Law Act, is to specify the state's priority activities in the area of public procurement, as

1 Hubert Izdebski, and Michał Kulesza, Administracja publiczna. Zagadnienia ogólne (Warsaw: Liber, 1998), 99-120.

2 Hubert Izdebski, and Michał Kulesza, Administracja publiczna. Zagadnienia ogólne, 99-120; Hubert Izdebski, Historia myśli politycznej i prawnej (Warsaw: C.H. Beck, 1996), 154-156; Marek Wierzbowski, Prawo gospodarcze. Zagadnienia publicznoprawne (Warsaw: WoltersKluwer, 2005), 27-28.

3 Dawid Sześciło, „Polityka publiczna i rola administracji w jej tworzeniu,” in $\mathrm{Ad}$ ministracja i zarządzanie publiczne. Nauka o wspótczesnej administracji, ed. Dawid Sześciło, (Warsaw: Wyd. Stowarzyszenie Absolwentów Wydziału Prawa i Administracji Uniwersytetu Warszawskiego, 2014), 58.

4 Jerzy Hausner, Zarzadzanie publiczne (Warsaw: Wyd. Scholar, 2008), 46 and next.

5 Act on Introductory Provisions Public Procurement Law of Day Month Year, Journal of Laws 2019, item 2020. 
well as the desired conduct of entities which has been awarded contracts, including in particular the purchase of innovative or sustainable products and services, taking into account in particular standardization aspects, calculations costs in the product life cycle, corporate social responsibility, dissemination of good purchasing practices and tools $s^{6}$. The state's purchasing policy is to be a strategic document setting out specific values and goals that, in a given period, should guide the public procurement process. Thus, the state's purchasing policy employs public procurement to engage with different areas of the state's operation.

\section{SHORT HISTORICAL OUTLINE}

Despite the fact that the concept of "state purchasing policy" has only recently appeared in the area of public procurement, we have been witnessing purchasing strategies and detailed actions in this field for many years. For example, the need to define clear guiding principles for public procurement appeared in the first years after Poland regained independence. Regulating the basic principles and forms of awarding government contracts while outlining the objectives of economic policy, to a large extent, contributed to the dynamic development of the country at that time ${ }^{7}$. An important element of building a uniform public procurement system was the establishment of the Distribution Office with the task of centralizing government procurement ${ }^{8}$. It was created at the Ministry of Industry and Trade. All government bodies were obliged to direct their orders for industrial products to the Distribution Office, which divided these orders between relevant industrial plants. The fact that a central public administration body was created to centralize government procurement pointed to the paramount need to harmonize legal solutions in this area, and to increase the efficiency of the awarded contracts. It was also the first step

6 Act on Public Procurement Law of day. Month, Year, Journal of Laws 2019, item 2019, as amended.

Andrzej Panasiuk, Publicznoprawne ograniczenia przy udzielaniu zamówień publicznych (Bydgoszcz - Warsaw: Oficyna Wydawnicza Branta, 2007), 16-23.

8 Decree of the Head of State on the creation of a Distribution Office to centralize government procurement, Journal of Laws 1918, No 19, item 55. 
towards pursuing an informed state policy in the area of public procurement. The adoption of the Act on Supplies and Works for the Treasury, Local Government, and Public Law Institutions on 15th February 1933 complemented the earlier actions ${ }^{9}$. This Act set out general principles for the distribution of public procurement, at the same time outlining the objectives of the State's economic policy. The post war years saw the economy transformed. The private sector was liquidated to significantly expand and strengthen the socialized sector. Thus, it was also necessary to adapt the provisions on public distribution, which have evolved towards a particular preference for the socialized sector ${ }^{10}$. The post-war State and its economy needed efficient instruments enabling the implementation of public objectives. Therefore, the times of introducing the principles of a planned economy controlled centrally by the state apparatus followed. The planned economy was an essential aspect of the operation of the state, for it was based on a central plan. Moreover, it allowed for the implementation of a command-and-control economy i.e. an economy where demand and supply are regulated by the state. Such a model of the economy lacked competition and thus, led to the misallocation of the state-owned factors of production. Economic plans were the basic method for exercising state control over economic processes. In the centrally planned economy model, so called, planned agreements played the role of public procurement. In the 1950s, an obligation to conclude planned agreements was introduced to comply with the rule of law, ensure discipline in the implementation of economic plans, improve cooperation in implementing these plans, and consolidate the principles of economic settlement. The ambit of the mutual rights of obligations provided for in the planned agreements extended to supply, sale, and transport of goods. Their size and scope resulted from the economic plans. Planned agreements covered the entire supply and sale plan as well as, if possible, the carriage of goods. The parties concluding

9 Act on Supplies and Works for the Treasury, Local Government, and Public Law Institutions on 15 February 1933 complemented the earlier actions, Journal of Laws 1933, No 19 , item 127.

${ }_{10}$ Act on supplies, works and services for the Treasury, local government and certain categories of legal persons of 18 November 1948, Journal of Laws 1948, No 63, item 494 and Act on planned contracts in the socialist economy of 19 April 1950, Journal of Laws 1950, No 50, item 180. 
the planned agreement were obliged to determine its content based on the economic plan, specifying mutual obligations, taking into account the general interests of the national economy and the principles of economic settlement. On the other hand, in the period immediately preceding the socio-economic changes taking place in the country, government orders were planned and conducted centrally by selected departmental units. Following the Socio-economic Planning Act of 26th February 1982, the Council of Ministers compiled, by a resolution, a list of goods which would be obtained via public procurement ${ }^{11}$. The aforementioned act employed the Council of Ministers to organise and supervise implementation of government orders. To ensure the proper implementation of important economic objectives, as well as improve the supply of particularly scarce resources, and ensure that government orders are fulfilled, the Council of Ministers, by resolution, formulated a list of raw materials and intermediate goods allocated for production purposes ${ }^{12}$. Generally, lists of such raw materials, materials and products covered by government procurement were established as part of central annual plans, and were only amended and supplemented by resolutions of the Council of Ministers ${ }^{13}$. The national plan, paramount in the period of centralist economic planning, had three functions: it pressured enterprises to perform planned tasks and achieve results according to the plan; it assessed the implementation of the above-mentioned objectives, productive efficiency, and overall enterprise's activity; as well as being the basis for the calculation of wages for the entire staff ${ }^{14}$.

Thus, since its very establishment public procurement was a conduit for implementation of state policy.

The state's purchasing policy in the light of European law European law does not refer to the economic results of specific contracts concluded

11 Act of the Council of Ministers of 26 February 1982, Journal of Laws 1987, No 4, item 26, as amended.

12 Resolution No. 280 of the Council of Ministers of December 30, 1982 regarding government procurement of materials and products, Journal of Laws 1983, No. 1, item 9.

13 Andrzej Panasiuk, Publicznoprawne ograniczenia przy udzielaniu zamówień publicznych, 23-34.

14 Zdzisław Dąbrowski, „Aktualne koncepcje planowania (gospodarki narodowej),” Ruch Prawniczy, Ekonomiczny i Socjologiczny, no. 1 (1984), 206. 
in the public procurement system. As illustrated by the directives coordinating public procurement, it focuses more on defining the increasing number of policy objectives which Member States may regard as generating significant additional costs. Therefore, each Member State in its purchasing policy must individually develop its approach to conducting policy promoting political goals, rather than minimizing the costs of such transactions. The implementation of specific non-purchasing goals, such as environmental protection, social requirements, or support for disadvantaged social groups, such as minorities or the disabled, always ensues higher transaction costs.

In European law, as S. Arrowsmith rightly points out, there are currently three main areas of interest when using public procurement to achieve political goals: - environmental protection through green public procurement, - social responsibility through socially responsible public procurement, - innovation through public procurement promoting innovation ${ }^{15}$.

When public procurement serves other policy objectives costs should always be compared with benefits ${ }^{16}$. Achieving non-shopping goals often entails paying higher prices, thereby negatively impacting the contractor's offer e.g. diminishing the service quality. The benefits of social and environmental requirements increase prices and restrict competition, as some contractors refrain from participating in public procurement procedures. In addition, there are costs to ensure compliance with contractual requirements. In general, additional costs may arise both due to additional costs incurred by contractors in meeting environmental or innovative requirements, and because some contractors cannot meet these requirements and therefore cannot participate at all, which limits competition. The EU public procurement directives based on the Treaty of Rome aim to create the European single market. Therefore, the European Union may pursue completely different goals than central and local governments of the Member States. Sometimes this policy can be difficult to implement without adversely affecting the local market, and thereby leading to the loss of local

15 Sue Arrowsmith, „Horizontal Policies in Public Procurement. A Taxonomy”, Journal of Public Procurement, no. 10(2) (2010), 149-186.

16 Christopher Mccrudden, Buying Social Justice: Equality, Government Procurement \& Legal Change (Oxford: Oxford University Press, 2007), 594-617. 
jobs and even the bankruptcy of local companies. Increased use of policy objectives contained in public procurement can often result in additional administrative burdens and thus, costs for local authorities.

The provisions on public procurement are being reviewed in Europe each time a new package of directives coordinating public procurement procedures is developed ${ }^{17}$. Usually during the debates regarding the direction of change two opposite positions emerge. First calls for more active use of public procurement as a policy tool to stimulate innovation, green technologies and social inclusion. This, however, would require more flexible public procurement instruments and ex post monitoring of results to reduce their abuse. The second favours further integration of the European market, and thus the introduction of provisions that limit the use of flexible procedures and control ex ante procedures instead of ex post results. For some time, we have been able to observe a trend that every change in the package of directives coordinating the award of public contracts includes an increasing number of policy objectives. This can be beneficial at some levels and for particularly privileged groups. At the same time, however, it may cause conflicts of interest with other levels, as in the case of contracts awarded by specific groups of public entities. Basically, every new goal has additional costs and can limit competition, which can increase prices. As a result, public entities can obtain less favourable offers compared to the private sector.

To reduce the negative aspects related to the use of policy objectives in public procurement, the public sector should simplify and standardize public procurement policies, often seeking alternative solutions.

\section{THE ROLE AND SCOPE OF PURCHASING POLICY}

Due to the fact that strategic planning is long-term and focused on defining and achieving specific goals the state's purchasing policy should

17 Directive 2014/24 / EU of 26 February 2014 on public procurement, repealing; Directive 2004/18 / EC. Directive of 26 February 2014 on the award of contracts by entities operating in the water, energy, transport and postal services sectors, repealing; Directive 2004/17 / EC. Directive 2014/23 / EU of 26 February 2014 on the award of concessions. 
stem from the state's development strategy. The operational planning strategy facilitates the concentration of organizational resources. While it focuses only on basic activities, such as directions of the undertaken activities it also significantly reduces functional uncertainty caused by an evolving environment, thereby increasing adaptability ${ }^{18}$.

Purchasing policy should be treated as one of the instruments for implementing the state's development strategy. Its objectives should be closely related to long-term socio-economic policy. These goals should reflect the socio-economic needs determined by the external and domestic condition, the basic requirements of the political system and the value system of various social groups.

The basic document which refers to the state's purchasing policy is currently the Strategy for Responsible Development for the period up to 2020 (including the perspective up to 2030). The midterm Strategy for Responsible Development for the period up to 2020 is a pivotal document for the activities concerning the country's economy. The basic assumption of the Strategy is that the Polish economy needs new development impulses that will ensure stable competitiveness growth based on different development factors such as: growing role of knowledge and technology in the economic processes; development and further expansion of Polish companies; establishment of a savings system; increasing quality of institutions and their social interaction. They must supplement the current factors including low labour costs, inflow of foreign investments, increase in education quality, and structural changes resulting from EU membership. While public procurement is to play an important role in implementing the strategy the state's purchasing policy has been identified as a strategic project included in the area of reindustrialization of the midterm national development strategy.

In its essence, the purchasing policy of the state must primarily focus on implementing the assumptions of the midterm strategy. However, at the lowest level the public procurement procedure is driven by the basic rule of achieving the greatest benefit because the ultimate goal of public procurement is to ensure a cost-efficient public expenditure. This key

18 James A.F. Stoner, and Charles Wankel, Kierowanie (Warsaw: Państwowe Wydawnictwo Ekonomiczne, 1992), 99-100. 
principle appreciates not only the price of goods or services, but also their suitability and quality. The criterion of cost-efficiency can be defined as "the optimal combination of lifetime costs and quality to meet customer requirements ${ }^{19}$." However, imposition of additional requirements to serve political needs (e.g. environmental, social or innovative goals) distorts the cost-efficiency analysis. Most procurement systems aim to promote competition and economic benefits. However, there are often other conflicting goals, such as promoting allocative efficiency, customer satisfaction, risk avoidance, and promoting a uniform ecological approach ${ }^{20}$.

As the above considerations show, various goals potentially included in the purchasing policy are inconsistent. Therefore, some degree of political compromise seems inevitable. For example, cost-effectiveness requirements may favour large foreign contractors over of a small local company. Thus, the potential positive effect on the local market is foregone. The doctrine emphasizes that private sector rarely takes into account transparency let alone higher price for it often turns out to be contrary to accepted commercial practices. However, there is a widespread agreement that policy should play a fundamental role in spending public fund $\mathrm{s}^{21}$.

Political instruments and objectives mainly relate to the order itself and do not engage with the entire cycle - from identifying the need for purchase through the purchasing process itself to the implementation of the contract - despite the barriers which are present at these stages and the fact that they generally involve a wider set of actors and stakeholders. Therefore, purchasing policy should also address these issues. Purchasing policy is usually seen as a legal tool to stimulate domestic production and consumption. By entering into agreements on specific sectors or social groups, the state can redistribute wealth, promote industrial strategies or ensure sustainable development.

19 Kim Loader, „The Challenge of Competitive Procurement: Value for Money Versus Small Business Support,” Public Money \& Management, no. 27 (2007): 307-314.

20 Steven L. Schooner, "Desiderata: Objectives for a System of Government Contract Law," Public Procurement Law Review, no. 11 (2002): 103.

21 Steven L. Schooner, "Commercial Purchasing: the Chasm between the United States Government's Evolving Policy and Practice," in Public Procurement: the Continuing Revolution, ed. Sue Arrowsmith, and Martin Trybus (London: Kluwer Law International, 2002), 63. 


\section{IMPLEMENTATION OF THE STATE'S PURCHASING POLCY}

The development of the state's purchasing policy will not alone bring the expected results, unless its implementation is not appropriately regulated, both at the level of central and local authorities. Purchasing policy as a public sector operating strategy will be determined not only by internal conditions prevailing in the administration itself, but also by the external environment, which will have a decisive impact on its implementation, in connection with, e.g., globalization or integration processes, so as to be able to effectively facilitate socio-economic development.

The implementation of the purchasing policy will consist of a number of activities aimed at achieving the goals set in the policy, outlining the appropriate tools to achieve these goals, and then monitoring their implementation. Direction and objectives of the purchasing policy should originate from the analysis of the socio-economic environment of the state. Appropriate instruments should be assigned to each goal to enable its implementation through procurement. Policy designers should, first of all, answer the questions of what they want to achieve, what values they want to protect, and what they want to avoid. Only then it is possible to indicate the goals, develop proper strategies, design proper tools, and eventually assess them.

The state's purchasing policy is a long-term document that can be modified to reflect changing external conditions and new objectives that emerge. Under the draft Public Procurement Law Act, the state's purchasing policy is to be developed every 4 years and adopted by the Council of Ministers by way of a resolution, at the request of the Minister of Finance (Art. 21 of the Act of 11 September 2019, Public Procurement Law Act). The Minister will also be responsible for preparing the project and coordinating its implementation.

The document of the state's purchasing policy itself remains inoperative unless there are specific rules for its implementation at certain levels of public administration. The legislator's actions in this respect should be appreciated, because in accordance with the instruction of Art. 22 of the draft Public Procurement Law Act, the contracting authority being the central government administration body, prepares a management strategy for individual purchasing categories, in line with the purchasing policy of the state. The strategy specifies key orders for the implementation of the state's 
purchasing policy. Therefore, the strategy is an executive document of the state's purchasing policy, practically used by the institutions awarding public tenders.

Central orders as well as joint orders can serve as good tools for achieving the objectives of the country's purchasing policy efficiently.

European legislators already introduced the central contracting authority in the package of directives coordinating public procurement procedures in 2004. In our national legal order, this institution was established in 2006 by the Public Procurement Law Act seeking to implement Directive 2004/18 /EC of the European Parliament and of the Council of 31 March 2004 on the coordination of procedures for the award of public contracts for works, supplies and services ${ }^{22}$. During the next review of EU directives, which resulted in the adoption of a new package of directives in 2014, this legal institution was refined. Currently, art. 2(1)(14) of the Directive 2014/24 / EU ${ }^{23}$ defines the concept of "centralized purchasing activities" as activities conducted on permanent basis. The implemented legal structure allowed the awarding entities, pursuant to art. 4 (11) of the Public Procurement Law Act, for purchasing orders from the central contracting authority or from contractors selected by it without applying the act. It concerned government administration and was aimed at merging large orders. When the state's purchasing policy enters into force, it should be implemented through purchasing activities carried out by central procuring entities.

\section{CONCLUSIONS}

The introduction of the obligation to develop a purchasing policy into Polish public procurement law should be considered as the next step to-

22 Directive 2004/18 / EC of the European Parliament and of the Council of 31 March 2004 on the coordination of procedures for the award of public contracts for works, supplies and services, Journal of Laws L 134 of 2004, s. 114, as amended.

23 Directive of the European Parliament and of the Council of 26 February 2014 on public procurement, repealing Directive 2004/18 / EC, O.J.E.C., L 94 z 28.03.2014 r., s. 65 and Articles 55-57 of Directive 2014/25 / EU, concerning centralized purchasing activities and procurement involving contracting entities from different Member States, were formulated in a very similar way as the provisions of Art. 37-39 of Directive 2014/24 / EU. 
wards the rational use of public procurement in accordance with the current needs of the state. The action of the national legislator results from changes in European law, which is evolving towards the use of public procurement for policy purposes other than strictly purchasing. As M. Szydło indicates economic planning as a state intervention in the economy, is also a natural instrument in the social market economy. The modern state, willing to minimize its intervention in the economy, is somewhat forced to introduce strategic planning in all its aspects. ${ }^{24}$ Therefore, in order for the purchasing policy to be implemented efficiently, procuring institutions must be aware of the purpose set by the legislator. Therefore, one must be aware of the objective and know the tools at one's disposal to fully and effectively implement purchasing policy.

\section{REFERENCES}

Arrowsmith, Sue. "Horizontal Policies in Public Procurement. A Taxonomy." Journal of Public Procurement, no. 10(2) (2010): 149-186.

Dąbrowski, Zdzisław. "Aktualne koncepcje planowania (gospodarki narodowej)." Ruch Prawniczy, Ekonomiczny i Socjologiczny, no. 1 (1984): 206.

Dąbrowski, Zdzisław. "Aktualne koncepcje planowania (gospodarki narodowej)." Ruch Prawniczy, Ekonomiczny i Socjologiczny, no. 1 (1984): 206.

Hausner, Jerzy. Zarzadzanie publiczne. Warsaw: Wyd. Scholar, 2008.

Izdebski, Hubert, and Michał Kulesza. Administracja publiczna. Zagadnienia ogólne. Warsaw: Liber, 1998.

Izdebski, Hubert. Historia myśli politycznej i prawnej. Warszawa: C.H. Beck, 1996. Loader, Kim. "The Challenge of Competitive Procurement: Value for Money Versus Small Business Support.” Public Money \& Management, no. 27 (2007): 307-314.

Mccrudden, Christopher. Buying Social Justice: Equality, Government Procurement \& Legal Change. Oxford: Oxford University Press, 2007.

Panasiuk, Andrzej. Publicznoprawne ograniczenia przy udzielaniu zamówień publicznych. Bydgoszcz - Warsaw: Oficyna Wydawnicza Branta, 2007.

24 Marek Szydło, "Planowanie indykatywne jako funkcja państwa wobec gospodarki," in Funkcje wspótczesnej administracji gospodarczej. Księga dedykowana Profesor Teresie Rabskiej, ed. Barbara Popowska (Poznań: Wydawnictwo Poznańskie, 2006), 148. 
Schooner, Steven L. "Commercial Purchasing: the Chasm between the United States Government's Evolving Policy and Practice." In Public Procurement: the Continuing Revolution, edited by Sue Arrowsmith, and Martin Trybus, 63. London: Kluwer Law International, 2002.

Schooner, Steven L. "Desiderata: Objectives for a System of Government Contract Law." Public Procurement Law Review, no. 11 (2002): 103.

Sześciło, Dawid. "Polityka publiczna i rola administracji w jej tworzeniu." In $A d-$ ministracja i zarządzanie publiczne. Nauka o wspótczesnej administracji, edited by Dawid Sześciło, 58. Warsaw: Wyd. Stowarzyszenie Absolwentów Wydziału Prawa i Administracji Uniwersytetu Warszawskiego, 2014.

Szydło, Marek. "Planowanie indykatywne jako funkcja państwa wobec gospodarki." In Funkcje wspótczesnej administracji gospodarczej. Księga dedykowana Profesor Teresie Rabskiej, edited by Barbara Popowska, 143-161. Poznań: Wydawnictwo Poznańskie, 2006.

Wierzbowski, Marek. Prawo gospodarcze. Zagadnienia publicznoprawne. Warsaw: WoltersKluwer, 2005. 